13. Серова Т. С. Обучение гибкому иноязычному профессионально ориентированному чтению в условиях деловой межкультурной коммуникации: монография. Пермь: Изд-во Пермского гос. техн. ун-та, 2009. 242 с.

Received date 06.08.2019

Accepted date 23.08.2019

Published date 30.09.2019

Перелома Тетяна Сергї̈вна, асистент, кафедра мов і літератур Далекого Сходу та Південно-Східної Азії Інституту філології, Київський національний університет імені Тараса Шевченка, вул. Володимирська, 60, м. Київ, Україна, 01033

E-mail: tanya199409@gmail.com

UDC 378.147

DOI: 10.15587/2519-4984.2019.179145

\title{
THE ROLE OF TEAMS GAMES TOURNAMENTS (TGT) AGAINST ACTIVITY OF LEARNING ELEMENTARY SCHOOL STUDENTS
}

\author{
Selia Wahyu Kaeksi, Farida Agus Setiawati
}

\begin{abstract}
Мета цьього дослідження - теоретично пояснити роль турнірних командних ігор (ТКІ) в учбовій діяльності учнів початкової иколи.

Багато факторів впливає на успішність учнів початкової школи, включаючи активність їхньої участі в навчанні. Належна учбова модель необхідна для оптимізації учбової діяльності. Коректна учбова модель має розвинути навички критичного мислення учнів та допомогти їм брати активну участь в учбовому прочесі. Учбова модель ТКІ допомогає учням мислити критично на турнірах та вікторинах. Учбові заняття можуть бути організовані через групове навчання в командах. Це стає можливим завдяки минулим дослідженням, щзо використовували модель ТКІ для формування навичок критичного мислення. Результати свідчать про покращення, іншими словами, більшу ефективність навичок критичного мислення.

Грунтуючись на результатах обговорення презентованих досліджень, зроблено теоретичний висновок: турнірні командні ігри (TKI) мають значення для учбової діяльності учнів початкової школи

Ключові слова: команди, ігри, турніри, діяльність, навчання, початкова школа, модель
\end{abstract}

Copyright (C) 2019, Selia Wahyu Kaeksi, Farida Agus Setiawati. This is an open access article under the CC BY license (http://creativecommons.org/licenses/by/4.0).

\section{Introduction}

The learning process is one important element for achieving success in learning [1]. In the learning process that happens the process of transformation of science and values. When the learning process takes place, there is an interaction between the teacher and students which makes it possible for the teacher to be able to recognize the characteristics and potential of the students. When learning, students have the opportunity to develop their potential so that this potential can be optimized. Therefore, education no longer provides a stimulus but an effort to develop its potential. That knowledge is not given, but is built by students [2].

Many factors affect student learning success, including the factors of students themselves, the environment, teacher factors, the level of difficulty of subject matter, and inadequate learning facilities. Likewise, elementary students, to be able to recognize and develop the potential of course in the learning process need active learning. Thus, students have ample opportunities to develop their abilities such as expressing opinions, thinking, conveying ideas or so on.
The learning process as a starting point for achieving learning success, the teacher as an educator has the task of directing students to be active during the learning process. The activeness of students can be seen by presenting learning and assignments in groups, giving problems that will later be solved individually or in groups. Through problem solving, students will get used to practicing critical thinking. Therefore, a teacher must know the needs and abilities of students and position students as learning subjects, so that in the learning process can make students active individually in understanding subject matter and critical thinking, and active in groups in collaboration and socializing.

\section{Literature review}

Critical thinking skills need to be owned by students as one of the provisions facing complex problems and life that continues to develop. Critical thinking is grown on students, can help students in dealing with problems and explore their potential. This becomes an important task for teachers to create learning that can help students develop critical thinking skills. Mulnix [3] 
say that the most effective strategy is to improve students 'critical thinking skills by paying attention to students' epistemological development, introducing active learning, problem-based curriculum, stimulating interaction between students, and learning in real life.

In the learning process, the learning model is a pattern that is used as a guide in planning learning in class. The learning model with cooperative learning gives students an understanding of the importance of group cooperation while still paying attention to individual efforts. According to Slavin [4] Cooperative learning is a learning model using a grouping or small team system, which is between four to six people who have different academic abilities, sex, race, or ethnicity (heterogeneous). Each group will get a reward, if the group is able to show the required achievements. Thus, each group will have a positive dependency which in turn will bring up individual responsibility towards the group. Each individual will help each other, they will have motivation for group success, so that each individual will have the same opportunity to contribute to the success of the group.

The cooperative learning model not only excels in helping students understand difficult concepts, but is also very useful for fostering critical thinking skills, working together, and helping friends. In cooperative learning, students are actively involved in the learning process so that it gives a positive impact on the quality of interaction and active learning. Activities in cooperative learning are mostly student-centered, such as studying subject matter, discussing to solve problems and complete assignments.

There are several types of cooperative learning models, one of which is the type of cooperative learning model Teams Games Tournaments (TGT). In TGT type cooperative learning students form small groups in classes consisting of 3-5 heterogeneous students, both in terms of academic, gender, race, and ethnicity. The essence of this model is the existence of games and academic tournaments. Playing the games with other team members to obtain scores for their respective teams. Games can be arranged in the form of quizzes in the form of questions related to the subject matter, can also be interspersed with questions related to the group.

\section{The aim and objectives of the study}

The purpose of this study is to explain theoretically about the role of teams games tournaments ( TGT ) on the learning activities of elementary school students .

To achieve the set aim, the following tasks have been solved:

1. To explain theoretically Team Games Tournament (TGT) in elementary school students.

2 . To explain theoretically activity of learning elementary school students.

\section{Materials and methods}

\section{1. Model Teams Games Tournaments (TGT)}

The TGT learning model is learning that places students in heterogeneous groups, then representatives of students from each group play games, then compete in an academic tournament or quiz $[4,5]$. the group would best be viewed from the acquisition of scores by all group members. through this learning model, students can learn to be active in groups and individually active through academic tournament.

For more details, the following are the stages in the TGT purchase model. According to Slavin [4], there are five stages in the steps of the TGT learning model: class presentations, teams, games, tournaments, and team recognition. The TGT model is learning that actively engages students in the learning process because students learn in teams, games, and tournaments. Class presentations show active interactions between students and teachers, while learning in teams shows active interactions between students in discussions and helping friends to understand the subject matter, thus encouraging students to be actively involved in learning. Games and tournaments can train students to take responsibility and hone critical thinking skills in solving problems given by the teacher.

\section{2. Active Learning}

The activeness of students in learning is an important and fundamental issue that must be understood, realized and developed by every teacher in the learning process. Learning activity is characterized by optimal involvement, both intellectual, emotional and physical. Students are active learning people and are always curious. This is in line with the opinion of Holt [6] which states that the learning process is more active if students do things as follows:

1) students re-express the information received in their own sentences so that it can be seen how much the student's understanding of information the said;

2) students give examples of the material obtained;

3) Students recognize the same thing;

4) students associate the information obtained with other facts or ideas;

5) students use various methods carried out in learning;

6) students predict several consequences obtained from the actions taken; a thing.

7) students mention opponents or the opposite of

The active power possessed by children naturally will be able to develop in a positive direction when the environment provides good space for the development of that activity. Crawford [7] argues that meaning, the teacher must begin the lesson by exploring concepts that have been previously learned by students and make them ready to learn by asking questions and setting goals for learning.

According to Sudjana \& Rivai [8] active learning can be seen from:

1) participating in carrying out learning tasks;

2) involved in problem solving;

3) ask other students or teachers if they do not understand the material or problems in the lesson;

4) trying to find various information needed to solve the problem;

5) carry out group discussions according to the teacher's instructions;

6) assessing his abilities and the results obtained; problems;

7) train yourself in solving similar problems or

8) use or apply that has been obtained in completing the task. 
Djamarah \& Zain [9] divides activities into several learning activities as follows:

1) listening;

2) looking at;

3) touch, smell, and taste / taste;

4) write or take notes;

5) reading;

6) make an overview or summary and underline;

7) observing tables, diagrams and charts;

8) prepare papers or working papers;

9) remembering.

In line with the classification learning activities for eight groups, viz [10].

1) Visual activities include reading, looking at pictures, observing experiments, demonstrations, exhibitions, and watching others work.

2) Oral activities include the activity of expressing a fact or principle, linking an event, asking questions, giving advice, expressing opinions, interviewing, discussing and interrupting.

3) Listening activities include listening to the presentation of material, listening to conversations or group discussions.

4) Writing activities include writing stories, writing reports, writing essays, making summaries, doing tests and filling out questionnaires.

5) Drawing activities include drawing, making graphics, charts, diagrams, maps and patterns.

6) Motor activities include conducting experiments, selecting equipment, conducting exhibitions, making models, playing games, dancing and gardening.

7) Mental activities (mental activity) that is pondering, remembering, solving problems, analyzing, looking at relationships and making decisions.
8) Emotional activities (emotional activity), namely interests, differentiating, brave, calm and others.

\section{Result}

A teacher before doing the activity of learning, it is good to make learning designs first. The learning model is a pattern that is used as a guide in planning learning in the classroom, through this learning model it is expected that the characteristics of elementary school students can be well facilitated. By using the right learning model, students are expected to be trained in developing their critical thinking skills and can participate actively during the learning process.

Through the TGT learning model can train students to think critically in tournaments and quizzes. And student learning activities can be built through group learning in teams.

This was reinforced by research conducted by Martha Khalistyawati [11] using the TGT model for critical thinking skills, showing an increase from $10 \%$ to $31.4 \%$ or in other words the effectiveness of critical thinking skills using the TGT model increased by $21.43 \%$.

\section{Conclussion}

Based on the discussion of theoretical studies that have been presented theoretically reviews : teams games tournaments ( TGT ) have a role in the activity of learning in elementary school students.

Considering that no scientific studies have been published since 2012 on "Role Of Team Tour Games Team (TGT) Toward Elementary Student Learning Activities" Basics Of Elementary School "then this problem will be very interesting if the next step of the writer is to analyze into modern scientific research.

\section{References}

1. Goldie J. G. S. Connectivism: A knowledge learning theory for the digital age? // Medical Teacher. 2016. Vol. 38, Issue 10. P. 1064-1069. doi: https://doi.org/10.3109/0142159x.2016.1173661

2. Kalina C., Powell K. C. Cognitive and social constructivism: Developing tools for an effective classroom // Education. 2009. Vol. 130, Issue 2. P. 241-250.

3. Mulnix J. W. Thinking Critically about Critical Thinking // Educational Philosophy and Theory. 2012. Vol. 44, Issue 5. P. 464-479. doi: https://doi.org/10.1111/j.1469-5812.2010.00673.x

4. Slavin R. E. Cooperative Learning // Review of Educational Research. 1980. Vol. 50, Issue 2. P. 315-342. doi: https://doi.org/ $10.3102 / 00346543050002315$

5. Van Wyk M. M. The Effects of Teams-Games-Tournaments on Achievement, Retention, and Attitudes of Economics Education Students // Journal of Social Sciences. 2011. Vol. 26, Issue 3. P. 183-193. doi: https://doi.org/10.1080/09718923.2011.11892895

6. Holt J. C. Learning all the time. New York: Addison-Wesley, 1989.

7. Crawford B. A. Learning to teach science as inquiry in the rough and tumble of practice // Journal of Research in Science Teaching. 2007. Vol. 44, Issue 5. P. 613-642. doi: https://doi.org/10.1002/tea.20157

8. Sudjana N., Rivai A. Media pembelajaran. Bsndung: Sinar Baru, 2005.

9. Djamarah S. B., Zain A. Belajar dan pembelajaran. Jakarta: Rineka Cipta, 2002.

10. Nasution S. Berbagai pendekatan dalam proses belajar dan mengajar. Jakarta: Bina Aksara, 2000. 223 p.

11. Khalistyawati M., Muhyadi M. Pengaruh model STAD dan jigsaw terhadap karakter kerja sama, kemampuan berpikir kritis, dan hasil belajar kognitif // Jurnal Pendidikan Karakter. 2018. Vol. 8, Issue 2. P. 187-205.

Received date 07.09.2019

Accepted date 15.09.2019

Published date 30.09.2019

Selia Wahyu Kaeksi, Primary Education, Postgraduate Program, Yogyakarta State University, Colombo str., 1, Karang Malang, Caturtunggal, Depok District, Sleman Regency, Daerah Istimewa Yogyakarta, Indonesia, 55281 E-mail: seliakaeksii@gmail.com

Farida Agus Setiawati, Faculty of Education, Yogyakarta State University, Colombo str., 1, Karang Malang, Caturtunggal, Depok District, Sleman Regency, Daerah Istimewa Yogyakarta, Indonesia, 55281

E-mail: faridaagus@uny.ac.id 